\title{
Hypokalemia, a Factor Influencing Renal Bicarbonate Reabsorption: Continued Studies on the Regulatory Mechanisms Governing Renal Handling of Acid-Base in Children
}

\author{
O. Oethlker ${ }^{(20)}$, S. Schultz, B. SchütT, A. Donath, And E. Rossi \\ Renal Unit, Department of Pediatrics, University of Berne, Berne, Switzerland
}

\section{Extract}

In a program concerned with regulatory mechanisms influencing the renal contribution to acid-base balance in pediatric-aged subjects, two patients with hypokalemic alkalosis were studied. The relation of serum potassium level to proximal tubular bicarbonate reabsorption was assessed at different potassium levels during states of equal plasma volumes or equal extracellular fluid (ECF) volumes. Renal bicarbonate threshold was either determined by means of bicarbonate titration studies or estimated from urinary $\mathrm{pH}$ and simultaneous plasma bicarbonate concentration. Estimation of threshold was judged to be acceptable if $\mathrm{pH}$ values in urine were close to 6.2, thereby indicating little or no spilling of bicarbonate into the urine. Simultaneous plasma bicarbonate concentrations indicated renal bicarbonate threshold.

Patient NM exhibited a renal bicarbonate threshold of $25 \mathrm{mmoles} / \mathrm{liter}$ at a serum potassium level of $1.7 \mathrm{mval} / \mathrm{liter}$ and $20.5 \mathrm{mmoles} / \mathrm{liter}$ at a potassium level of 2.7 mval/liter. Plasma volume was 54.7 and $52.9 \mathrm{ml} / \mathrm{kg}$ body weight, respectively.

Patient BE showed a renal bicarbonate threshold of $24.3 \mathrm{mmoles} / \mathrm{liter}$ with an ECF volume of $474 \mathrm{ml} / \mathrm{kg}$ body weight and a serum potassium level of $1.7 \mathrm{mval} /$ liter; however, this patient exhibited a renal bicarbonate threshold of less than 21 mmoles/liter with an ECF volume of $454 \mathrm{ml} / \mathrm{kg}$ body weight and a potassium level of $3.2 \mathrm{mval} / \mathrm{liter}$.

In both patients, renal bicarbonate threshold decreased when serum potassium levels increased. Moreover, plasma volume in one patient and ECF volume in the other either had decreased slightly or had remained essentially unchanged. Hence, an indirect relation was found between serum potassium level and renal bicarbonate threshold. Plasma volume, known to influence renal bicarbonate threshold, was without effect on this relation.

\section{Speculation}

In hypokalemic alkalosis the level of serum potassium itself or the levels of serum potassium as indicators of whole body potassium might be among the factors influencing renal bicarbonate reabsorption. 


\section{Introduction}

Contraction of extracellular fluid volume (ECF) by diuretics leads to alkalosis [4]. Experimental evidence had been advanced that the alkalosis is due to an increased proximal tubular bicarbonate reabsorption [11]. In earlier studies in two patients with Lowe's syndrome, a relative volume contraction was found to influence acid-base equilibrium [14]; in man, plasma volume was shown to be inversely related to renal bicarbonate threshold. In patients with hypokalemic alkalosis, ECF volume may play a major role in the genesis of the disorder, as it probably did in the patients treated with massive doses of sodium penicillin by Brunner and Frick [3]. The observation by Houston et al. [9], in a patient with the Fanconi syndrome, that metabolic alkalosis was not completely correctable by sodium supplements (correction of volume) alone points to the role of potassium as a factor influencing renal handling of hydrogen ion. In a carefully designed micropuncture study [11] using potassium-depleted rats, the effect of potassium depletion was clearly dissociated from that of ECF volume contraction. It should be emphasized, however, that species differences might have to be considered in evaluating the effects of hypokalemia on renal function [1].

As an extension of studies concerned with mechanisms influencing renal handling of acid-base in man, a protocol has been designed to demonstrate the relation of potassium with bicarbonate reabsorption by means of clearance techniques. Much care was given to maintain extracellular fluid volume at unchanged levels [18].

\section{Case Histories}

Patient NM appeared to have normal postnatal development until the age of 15 montlis. At this time, however, his mother reported that the patient lost his appetite and did not thrive well. After a viral infection, at 17 months of age, body weight had decreased by $2000 \mathrm{~g}$. At 20 months of age another infection occurred with fever and vomiting. The patient was severely dehydrated in the course of a few days and was hospitalized for treatment and work-up. Together with clinical signs of severe dehydration a hyponatremia of 111 mval/liter was found, a hypokalemia of $1.7 \mathrm{mval} /$ liter and almost normal acid-base equilibrium: blood $\mathrm{pH}$ was 7.463 , base-excess was -1 mval/liter, and $\mathrm{pCO}_{2}$ was $30.5 \mathrm{~mm} \mathrm{Hg}$. In the emergency ward a frank alkalosis became apparent after rehydration and correction of hyponatremia by infusion of plasma. Blood $\mathrm{pH}$ after infusion was now 7.423 , base-excess was $+5.2 \mathrm{mval} / \mathrm{li}$ ter, actual bicarbonate was $29.1 \mathrm{mmoles} / \mathrm{liter}$, and $\mathrm{pCO}_{2}$ was $47 \mathrm{~mm} \mathrm{Hg}$. The patient was transferred to the metabolic ward and work-up revealed a proximal tubular syndrome (Fanconi's). Clinical data revealed a generalized hyperaminoaciduria (excretion rate of alpha- $\mathrm{NH}_{2}-\mathrm{N}$ : $102 \mathrm{mg} / 24 \mathrm{hr}$, normal: $10-50 \mathrm{mg} / 24$ hr), no glucosuria, as judged by thin-layer chromatography of the urines, hyperphosphaturia (serum phosphate: $2.02 \mathrm{mg} / 100 \mathrm{ml}$, fraction of filtered phosphate reabsorbed: $30-50 \%$ ), serum calcium: $9.3 \mathrm{mg} / 100 \mathrm{ml}$, calciuria less than $4 \mathrm{mg} / 24 \mathrm{hr}$. During a l-week period of severe sodium and potassium restriction, sodium and potassium excretion rates were in equilibrium with intake at the beginning of the regimen and sodium excretion in the urine exceeded intake toward the end of the period. Sodium wastage was therefore established. During the period of hypokalemia the patient had significant electrocardiographic changes. No hyperaldosteronism was present as judged by an aldosterone excretion rate of $9.8 \mu \mathrm{g} / 24 \mathrm{hr}$, but determination of plasma renin revealed a value of $128 \mathrm{~m} \mu \mathrm{g} / \mathrm{liter} / \mathrm{min}$ (normal for age: $21 \pm 15 \mathrm{~m} \mu \mathrm{g} / \mathrm{liter} / \mathrm{min}$ ). Later, when electrolyte equilibrium was reached, the patient still exhibited adequate aldosterone excretion rates and normal plasma renin levels.

In this patient, determinations of serum sodium and potassium and character of renal handling of bicarbonate were obtained together with plasma volume measurements at different states of kalemia, hydration, and acid-base equilibrium. The lowest spontaneous urinary $\mathrm{pH}$ was 5.65 when acicl-base equilibrium in the patient was well balanced.

Patient $B E$ is a 1-year-old, second son of parents who are first cousins. His brother died at 14 months of age reportedly with severe growth retardation $(5700 \mathrm{~g})$ and a chronic hypopotassemia. Poorly described seizures had been noted throughout his life.

The development of the patient was normal until 4 months of age. At that time crises of very short duration which might have been seizure equivalents had been observed. In early infancy increasing anorexia was noted, and a polyuria developed with a tendency toward dehydration. Many diagnoses were considered such as hypovitaminosis D, hypovitaminosis B, hypoparathyroidism, but none of the consecutive therapeutic trials was successful. Thus, the patient was hospitalized at the University Children's Hospital, Berne, for work-up. On admission at 9 months of age the child 
was severely dystrophic. The patient presented with very distinct muscular weakness, but blood pressure, ophthalmologic responses, head circumference, skull x-rays, and electroencephalograms were normal. Chemical data showed a serum potassium level of 2.1 mval/liter, $\mathrm{pH}$ was $7.470, \mathrm{pCO}_{2}$ was $25.5 \mathrm{~mm} \mathrm{Hg}$, base-excess was $+1.2 \mathrm{mval} / \mathrm{liter}$, serum sodium level was $122 \mathrm{mval} / \mathrm{liter}$, calcium levels repeatedly were within normal limits, serum phosphorus level was 4.63 $\mathrm{mg} / 100 \mathrm{ml}$, chloride level was $95 \mathrm{mval}$, magnesium level was $2.4 \mathrm{mg} / 100 \mathrm{ml}$ (normal: $1.9-2.5 \mathrm{mg} / 100 \mathrm{ml}$ ), serum copper level was $167 \mu \mathrm{g} / 100 \mathrm{ml}$ (normal: $80-140$ $\mu \mathrm{g} / 100 \mathrm{ml}$ ), serum cholesterol level was $185 \mathrm{mg} / 100 \mathrm{ml}$ (uppermost limit of normal), and urinary concentrating ability was normal. Despite a slight hyponatremia of $130 \mathrm{mval} /$ liter urinary output of sodium slightly exceeded intake when the patient was fed a normal sodium and potassium diet. These findings are consistent with the assumption of an inability to conserve sodium sufficiently. Electrocardiographic changes correlating with severe hypokalemia persisted until correction of the potassium deficit. Plasma renin level was $83 \mathrm{~m}_{\mu \mathrm{g}}$ / liter/min (normal for age: $21 \pm 15 \mathrm{~m} \mu \mathrm{g} / \mathrm{liter} / \mathrm{min}$ ). Aldosterone excretion was not determined. There was a nonspecific hyperaminoaciduria of $63-92.1 \mathrm{mg}$ of alpha- $\mathrm{NH}_{2}-\mathrm{N} / 24 \mathrm{hr}$ (normal: 7-35 mg/24 hr), and no glucosuria as judged by thin-layer chromatography of the urines. The BUN, serum proteins, and protein fractions were normal. A renal biopsy showed no glomerular or tubular abnormalities and no hyperplasia of the juxtaglomerular apparatus. In summary, a syndrome of renal sodium and potassium loss was found, which was unlike Bartter's syndrome despite some clinical and biochemical resemblance. In this patient correlation between renal bicarbonate reabsorption and kalemia was studied. Renal handling of bicarbonate will be reported at different levels of serum potassium together with corresponding ECF volume.

The common feature of hypokalemic alkalosis in both patients justifies describing them together in a study on the influence of kalemia on renal bicarbonate reabsorption.

\section{Design of Study}

During work-up and treatment, when renal handling of bicarbonate was examined, conditions changed with respect to kalemia and to plasma volume or ECF volume. Only two conditions, however, were of value to resolve the question of whether kalemia itself can be related to renal handling of bicarbonate. These are low and high concentrations of potassium in serum with unchanged volumes of ECF or plasma.

To compare renal handling of bicarbonate, it is necessary to use a well defined situation of acid-base equilibrium [15]. This state is best achieved by determination of renal bicarbonate threshold, which arbitrarily describes the plasma level of $\mathrm{HCO}_{3}$ - in millimoles per liter at which a urinary excretion rate of 0.02 mmoles $\mathrm{HCO}_{3} / 100 \mathrm{ml}$ GFR occurs. It can be determined in bicarbonate titration studies [14]. When it was not possible to perform bicarbonate titration studies, a simplified method of estimating renal bicarbonate threshold was used instead.

\section{Methods}

\section{Bicarbonate Titration Studics}

To produce a slight relative acidosis at the beginning of the examination, $75 \mathrm{mEq} / \mathrm{m}^{2}$ of $\mathrm{NH}_{4} \mathrm{Cl}$ were given orally as a $10 \%$ aqueous solution during the 4th hr preceeding the bicarbonate titration. During the titration study urine was collected through an indwelling urethral catheter, and venous blood samples were obtained from an indwelling needle that was flushed with a slightly heparinized isotonic saline solution after each sampling. Saline solution $(0.85 \% \mathrm{NaCl})$ was administered into another vein at a rate of $1 \mathrm{ml} / \mathrm{m}^{2} / \mathrm{min}$. The infusion following a priming injection of $1 \mathrm{ml} / \mathrm{kg}$ inulin $10 \%$ contained inulin calculated to maintain a blood level of $50 \mathrm{mg} / 100 \mathrm{ml}$. Control clearance periods were taken, after which time bicarbonate was added to the infusion to increase the serum bicarbonate level about 2 mmoles/liter/hr. When the bicarbonate threshold was passed, as judged by an increase of urinary $\mathrm{pH}$ to 6.5 , a few more clearance periods were completed and the study terminated.

\section{Estimation of Bicarbonate Threshold}

It is well known that very little bicarbonate is de. tected in a urine of a $\mathrm{pH}$ of 6.5 , at least in patients with normal or moderately reduced GFR. At renal bicarbonate threshold urinary $\mathrm{pH}$ is usually found to be higher than 6.2 [13]. Therefore, in some conditions timed spontaneous urine specimens were collected and at the same time blood $\mathrm{pH}, \mathrm{pCO}_{2}$, and plasma bicarbonate concentrations were determined. If urinary $\mathrm{pH}$ was between 6.5 and 6.2 , the corresponding plasma bicarbonate level was cautiously assumed to represent renal bicarbonate threshold, since urinary bicarbonate excretion would not markedly exceed 0.02 mmole $\mathrm{HCO}_{3} / 100$ 
Table I. Estimation of renal bicarbonate threshold in patient $N M$ (19.5 months)

\begin{tabular}{|c|c|c|c|c|c|c|c|}
\hline \multirow[b]{2}{*}{ Date } & \multicolumn{3}{|c|}{ Blood } & \multirow[b]{2}{*}{$\begin{array}{c}\text { Urine, } \\
\text { pH }\end{array}$} & \multirow{2}{*}{$\begin{array}{c}\text { Ka- } \\
\text { lemia, } \\
\text { mEq/ } \\
\text { liter }\end{array}$} & \multirow{2}{*}{$\begin{array}{c}\text { Plasma } \\
\text { vol- } \\
\text { ume, } \\
\mathrm{ml} / \mathrm{kg} \\
\text { body } \\
\text { wt }\end{array}$} & \multirow{2}{*}{$\begin{array}{c}\text { Esti- } \\
\text { mated } \\
\text { renal } \\
\text { bicar- } \\
\text { bonate } \\
\text { thres- } \\
\text { hold, } \\
\text { mmoles } \\
\text { liter } \\
\text { serum }\end{array}$} \\
\hline & pII & $\underset{\mathrm{mm} \mathrm{Hg}}{\mathrm{pCO}_{2}}$ & $\begin{array}{l}\mathrm{HCO}_{3}^{-} \\
\text {mmoles/ } \\
\text { liter } \\
\text { plasma }\end{array}$ & & & & \\
\hline $7 / 15 / 70$ & 7.390 & 42 & 25.3 & 6.50 & 1.70 & & 25 \\
\hline $7 / 16 / 70$ & 7.440 & 39 & 28.5 & 6.85 & 1.69 & 54.7 & \\
\hline
\end{tabular}

ml GFR. If urinary $\mathrm{pH}$ was above 6.5 , the corresponding plasma bicarbonate concentration was noted to be higher than renal bicarbonate threshold. A plasma bicarbonate concentration corresponding to a urinary $\mathrm{pH}$ of less than 6.2 was interpreted to be lower than renal bicarbonate threshold.

\section{Plasma and ECF volume}

Plasma volume was measured using the radioisotope dilution technique with ${ }^{131}$ I-labeled human albumin [16]. The ECF volume was determined according to Veall and Vetter [17], by measuring the corrected bromine space with ${ }^{82} \mathrm{Br} 1$ day before the corresponding examination, since equilibration of the substance affords $24 \mathrm{hr}$.

\section{Laboratory Methods}

Blood $\mathrm{pH}$ status, urine $\mathrm{CO}_{2}$ content and bicarbonate, serum clectrolytes, and inulin levels were determined as described earlier [14].

\section{Results}

\section{Patient NM}

Data of simplified studies for estimation of renal bicarbonate threshold appear in Table I, revealing plasma bicarbonate levels of 25.3 and 28.5 mmoles/liter that correspond to urinary $\mathrm{pH}$ of 6.5 and 6.85 , respectively. From these data renal bicarbonate threshold is cautiously estimated to be 25 mmoles/liter (see (lesign of study). Serum potassium was simultaneously $1.7 \mathrm{mEq} /$ liter; plasma volume was $54.7 \mathrm{ml} / \mathrm{kg}$ body weight. These values were obtained after a clietary regimen of 1 week's duration offering $5 \mathrm{mval} \mathrm{Na} / 24 \mathrm{hr}$ and $6 \mathrm{mval} \mathrm{K} / 24 \mathrm{hr}$. No hyperaldosteronism was present (sec description of patient). Thereafter the diet of the patient contained $75 \mathrm{mval} \mathrm{Na} / 2+\mathrm{hr}$ and $30 \mathrm{mval}$ $\mathrm{K} / 24 \mathrm{hr}$. Table II shows the bicarbonate titration study in patient $N M$ after 1 week of such a regimen. At a plasma bicarbonate of 21.7 mmoles/liter and a urinary $\mathrm{pH}$ of 6.68 , renal bicarbonate excretion was 0.045 mmole/100 $\mathrm{ml}$ GFR. This value exceeded the excre-

Table II. Bicarbonate titration study in patient NMI (20 months)

\begin{tabular}{|c|c|c|c|c|c|c|c|c|c|c|c|}
\hline \multirow{3}{*}{ Time, $\min$} & \multicolumn{3}{|c|}{ Blood } & \multicolumn{2}{|c|}{ Urine } & \multirow{3}{*}{$\underset{\mathrm{ml} / \mathrm{min}^{2}}{\mathrm{CIn}_{\mathrm{In}} / 1.73}$} & \multicolumn{3}{|c|}{ Bicarbonate } & \multirow{3}{*}{$\begin{array}{l}\text { Kalemia, } \\
\text { mEq/liter }\end{array}$} & \multirow{3}{*}{$\begin{array}{c}\text { Plasma } \\
\text { volume } \\
\mathrm{ml} / \mathrm{kg} \\
\text { body } \\
\mathrm{wt}\end{array}$} \\
\hline & \multirow{2}{*}{$\mathrm{pH}$} & \multirow{2}{*}{$\underset{\mathrm{mm} \mathrm{lig}}{\mathrm{pCO}}$} & \multirow{2}{*}{ 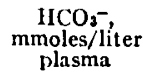 } & \multirow{2}{*}{$\begin{array}{c}V_{1} \\
\mathrm{ml} / \mathrm{min} / \\
1.73 \mathrm{~m}^{2}\end{array}$} & \multirow{2}{*}{$\mathrm{pH}$} & & \multicolumn{3}{|c|}{ mmoles/100 ml GFR } & & \\
\hline & & & & & & & Filtered & Excreted & Reabsorbed & & \\
\hline \multicolumn{12}{|l|}{-300} \\
\hline-240 & $\mathrm{NH}_{3} \mathrm{Cl}^{1}$ & & & & & & & & & & \\
\hline-140 & 7.37 & 34.0 & 19.0 & & & & & & & & \\
\hline 0 & \multicolumn{11}{|c|}{ Priming dose of inulin ${ }^{2}$} \\
\hline 2 & \multicolumn{11}{|c|}{ Start infusion ${ }^{3}$} \\
\hline $33-56$ & 7.37 & 30.5 & 17.0 & 6.85 & 6.52 & 37.2 & 1.700 & 0.018 & 1.682 & 2.48 & \\
\hline $57-78$ & 7.37 & 31.7 & 17.6 & 6.05 & 6.30 & 32.0 & 1.760 & 0.013 & 1.747 & 2.39 & \\
\hline \multirow[t]{2}{*}{$79-100$} & 7.38 & 32.0 & 18.4 & 4.24 & 6.30 & 26.3 & 1.840 & 4 & & 2.27 & \\
\hline & \multicolumn{11}{|c|}{ Infusion as above with addition 5} \\
\hline $101-138$ & 7.39 & 32.8 & 19.6 & 4.44 & 6.22 & 33.0 & 1.960 & 0.003 & 1.957 & 2.39 & \multirow{5}{*}{52.9} \\
\hline $139-158$ & 7.44 & 32.6 & 21.7 & 6.66 & 6.68 & 44.3 & 2.170 & 0.045 & 2.125 & 2.37 & \\
\hline 180 & Plasma volume & & & & & & & & & & \\
\hline $159-183$ & 7.45 & 33.8 & 23.4 & 5.59 & 6.86 & 29.3 & 2.340 & 0.082 & 2.258 & 2.33 & \\
\hline $184-209$ & 7.48 & 32.1 & 23.6 & 6.29 & 6.93 & 40.1 & 2.360 & 0.088 & 2.272 & 2.35 & \\
\hline
\end{tabular}

$1 \mathrm{~g}$ given by mouth as $10 \%$ watery solution.

$20.75 \mathrm{~g}$.

${ }^{3} \mathrm{NaCl}$ and glucose solution delivering $7 \mathrm{mg}$ inulin/min.

4 Not determined owing to technical accident.

5 Delivering $14 \mu \mathrm{Eq} \mathrm{HCO}_{2}-/ \mathrm{min}$. 
tion rate of $0.020 \mathrm{mmole} / 100 \mathrm{ml}$ GFR. In plotting bicarbonate excretion rates against plasma bicarbonate concentration (Fig. 1), a titration curve was drawn by inspection. The curve intercepted with the excretion rate of 0.020 mmole $\mathrm{HCO}_{3}-/ 100 \mathrm{ml} \mathrm{GFR}$ at a plasma $\mathrm{HCO}_{3}{ }^{-}$of $20.5 \mathrm{mmoles} /$ liter, thereby estimating the renal bicarbonate threshold. Serum potassium concentration was $2.37 \mathrm{mEq} / \mathrm{liter}$, plasma volume was $52.9 \mathrm{ml} / \mathrm{kg}$ bodly weight. The GFR was decreased to 40

OCTEPMIMUTION OF REXUL $\mathrm{HCO}_{3}^{-}$THRESHCL

(K.M. $20 \infty 0$ )

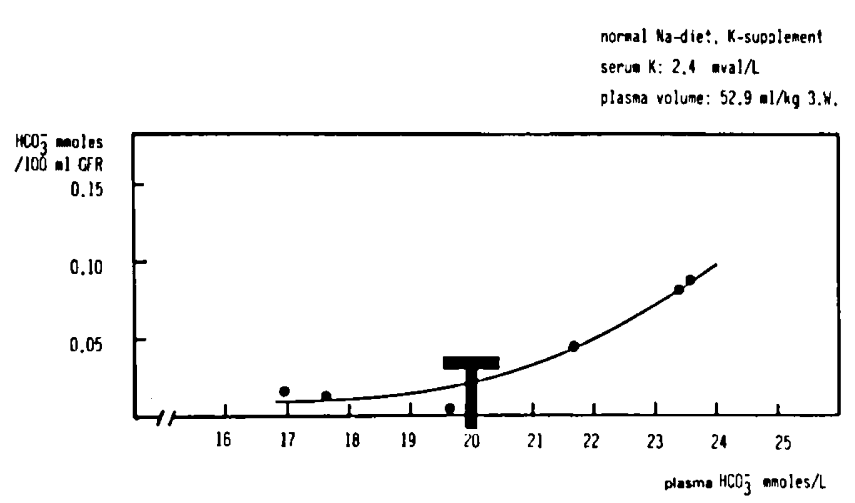

Fig. 1. listimation of renal bicarbonate threshold by means of a titration curve in patient $\mathrm{NM}, 20$ months. Plotting of $\mathrm{HCO}_{3}^{-} \mathrm{ex}$ cretion/100 $\mathrm{ml}$ GFR against plasma HCO ${ }_{3}-$ The points represent the actual measurements. The line has been drawn by inspection. $\Gamma$ marks the intercept of this line with a $\mathrm{HCO}_{3}^{-}$excretion of 0.02 mmoles $/ 100 \mathrm{ml}$ GFR. The corresponding plasma bicarbonate concentration indicates the level of renal bicarbonate threshold. $\mathrm{ml} / \mathrm{min} / 1.73 \mathrm{~m}^{2}$ and was unchanged 1 weck later, but had increased to $60 \mathrm{ml} / \mathrm{min} / 1.73 \mathrm{~m}^{2} 1.5$ months later.

Thus, a renal bicarbonate threshold of nearly 25 mmoles bicarbonate/liter plasma was found together with a serum potassium of $1.7 \mathrm{mEq} /$ liter. A renal bicarbonate threshold of nearly 20.5 mmoles bicarbonate/liter plasma was observed at a serum potassium concentration of $2.4 \mathrm{mEq} /$ liter. Plasma volume was 54.7 and $52.9 \mathrm{ml} / \mathrm{kg}$ body weight, respectively. Aldosterone excretion levels were low in both conditions.

\section{Patient BE}

Table III shows the results of a bicarbonate titration study in patient $B E$. These results were obtained after daily intake of $60 \mathrm{mEq} \mathrm{Na}$ and $20 \mathrm{mEq} \mathrm{K}$, respectively, for 1 week. At a plasma bicarbonate of 24.2 mmoles/liter just a significant amount of bicarbonate (0.028 mmole $/ 100 \mathrm{ml}$ GFR) appeared in the urine. From the graph (Fig. 2) of this study renal bicarbonate threshold was estimated at $\mathbf{2 4 . 0}$ mmoles/liter plasma. Scrum potassium levels were between 1.84 and 1.61 $\mathrm{mEq} /$ liter; $\mathrm{ECF}$ volume was $474 \mathrm{ml} / \mathrm{kg}$ body weight. Although ECF volume had to be determined $24 \mathrm{hr}$ prior to the study, it is probably a representative value, since body weight had not changed. Normal GFR was observed throughout the study. After 1 week of unchanged sodium intake, but of intravenous infusion of 60-90 mval $\mathrm{K}$ daily, kalemia and electrocardiographic findings had improved. A new estimation of renal bicarbonate threshold was obtained.

Table III. Bicarbonate titration study in patient BE (10 months), ECF volume $=474 \mathrm{ml} / \mathrm{kg}$ body weight

\begin{tabular}{|c|c|c|c|c|c|c|c|c|c|c|}
\hline \multirow{3}{*}{ Time } & \multicolumn{3}{|c|}{ Blood } & \multicolumn{2}{|c|}{ Urine } & \multirow{3}{*}{$\underset{1.73 \mathrm{~m}^{2}}{\mathrm{C}_{\mathrm{In}},}$} & \multirow{2}{*}{\multicolumn{3}{|c|}{$\frac{\text { Bicarbonate }}{\text { mmoles } / 100 \mathrm{ml} \mathrm{GFR}}$}} & \multirow{3}{*}{$\begin{array}{l}\text { Kalemia } \\
\text { mEq/lite }\end{array}$} \\
\hline & \multirow{2}{*}{ pII } & \multirow{2}{*}{$\underset{\mathrm{mm} \mathrm{IIg}_{\mathrm{g}}}{\mathrm{pCO}_{2}}$} & \multirow{2}{*}{$\begin{array}{c}\text { IICOA- } \\
\text { mmole/liter } \\
\text { plasma }\end{array}$} & \multirow{2}{*}{$\underset{1.73 \mathrm{~m}^{2}}{\mathrm{~V}}$} & \multirow{2}{*}{ pH } & & & & & \\
\hline & & & & & & & Filtered & Excreted & Reabsorbed & \\
\hline-325 & & & & & & & & & & \\
\hline-265 & $\mathrm{NH}_{4} \mathrm{Cl}^{2}$ & & & & & & & & & \\
\hline-45 & 7.43 & 30.5 & 20.4 & & & & & & & \\
\hline 46 & Priming do & nulin² & & & & & & & & \\
\hline 47 & Start infusi & & & & & & & & & \\
\hline $9-122$ & 7.43 & 30.9 & 20.0 & 2.06 & 6.10 & $9+.4$ & 2.000 & & 2.000 & 1.42 \\
\hline $123-149$ & 7.45 & 31.7 & 21.4 & 2.99 & 6.48 & 115.6 & 2.140 & & 2.140 & 1.64 \\
\hline 159 & Infusion as & with & dditiont & & & & & & & \\
\hline $268-284$ & 7.53 & 30.3 & 24.7 & 2.89 & 6.71 & 117.2 & 2.470 & 0.009 & 2.461 & 1.84 \\
\hline $285-305$ & 7.54 & 29.0 & 24.2 & 4.40 & 6.90 & 137.4 & 2.420 & 0.028 & 2.392 & 1.61 \\
\hline $306-326$ & 7.54 & 31.0 & 26.4 & 4.68 & 7.20 & 119.3 & 2.640 & 0.077 & 2.563 & 1.57 \\
\hline $327-348$ & 7.56 & 31.6 & 28.3 & 6.82 & 7.41 & 126.9 & 2.830 & 0.147 & 2.683 & 1.53 \\
\hline $349-372$ & 7.59 & 32.3 & 30.6 & 4.81 & 7.58 & 123.7 & 3.060 & 0.162 & 2.898 & 1.50 \\
\hline
\end{tabular}

$1 \mathrm{~g}$ given by mouth as $10 \%$ watery solution.

$20.55 \mathrm{~g}$.

${ }^{3} \mathrm{NaCl}$ and glucose solution delivering $8 \mathrm{mg}$ inulin/min.

$111 \mu \mathrm{Eq} \mathrm{HCO}_{2}-\mathrm{min}$. 
Measurements of two timed urine specimens are given in Table IV together with a simultancous blood $\mathrm{pH}$ status. At a plasma bicarbonate of 21.4 mmoles/liter the urinary $\mathrm{pH}$ was 7.45 and 7.55 , respectively. In addition, inulin clearances have been measured continuously during this period of time. Rates of bicarbonate excretion were therefore measured and the excretion is given in mmoles/100 $\mathrm{ml}$ of GFR. It is evident that the bicarbonate threshold was far exceeded at a plasma bicarbonate of 21.4 mmoles/liter since bicarbonate excretion rate of 0.077 and 0.065 mmoles $/ 100 \mathrm{ml}$ of GFR had been noted. The serum level of potassium was 3.2 $\mathrm{mEq} /$ liter, ECF volume was $454 \mathrm{ml} / \mathrm{kg}$ body weight.

Whereas ECF volume during the two studies had decreased slightly, serum potassium levels had increased from 1.7 to $3.2 \mathrm{mEq} / \mathrm{liter}$. Simultaneously the bicarbonate threshold had decreased from at least 24 mmoles/liter to less than 21 mmoles/liter.

\section{Discussion}

Both patients, presenting in the initial phase of their disease with hypokalemic alkalosis, appeared to be nat-

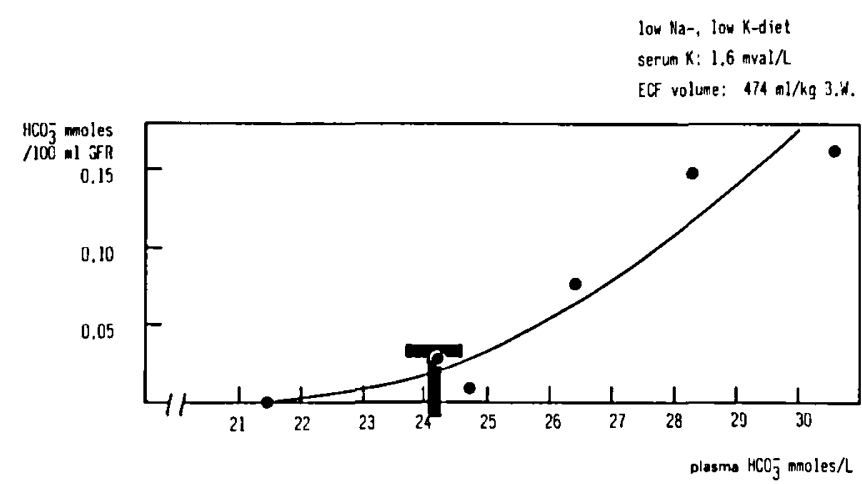

Fig. 2. Estimation of renal bicarbonate threshold by means of a titration curve in patient $\mathrm{BE}, 10$ months. Plotting of $\mathrm{HCO}_{3}{ }^{-}$ excretion $/ 100 \mathrm{ml} \mathrm{GFR}$ against plasma $\mathrm{HCO}_{3}{ }^{-}$. The points represent the actual measurements. The line has been drawn by inspection. $\mathrm{T}$ marks the intercept of this line with a $\mathrm{HCO}_{3}^{-}$ excretion of $0.02 \mathrm{mmole} / 100 \mathrm{ml} \mathrm{GFR}$. The corresponding plasma bicarbonate concentration indicates the level of renal bicarbonate threshold. ural models to study the relation of kalemia to the corresponding renal bicarbonate threshold.

Since plasma volume or ECF volume has been shown to be inclirectly related to renal bicarbonate threshold [11, 14], it was crucial for the present studies to relate only kalemia to renal bicarbonate threshold, when plasma or ECF volumes were identical or were slightly changed to have an opposite effect than kalemia might have had. The reported situations fulfill these criteria. Plasma volume or ECF volume was equal or slightly higher during potassium depletion than in a repleted state. Nevertheless, the increase of kalemia, i.e., potassium repletion, was associated with a distinct decrease of renal bicarbonate threshold. Thus, an effect of ECF volume was clissociated from the possible effect of potassium depletion.

It is conceivable that in potassium-depleted subjects tubular avidity for sodium could be increased because of hyperaldosteronism, thereby raising renal bicarbonate threshold. In patient NM the first study was undertaken after a period of low sodium intake. Aldosterone excretion rate, measured at the time of the first study, however, was low. In patient $B E$ aldosteronism, although not measured, was assumed not to have changed from one study to the other, since sodium intake was the same. It seems rather unlikely that tubular avidity for sodium was increased because of hyperaldosteronism which could have resulted in an increased renal bicarbonate threshold.

The increase of kalemia from 1.70 to 2.35 in patient $N M$ and from 1.6 to 3.2 in patient $B E$ was clearly beyond technical error. Thus, in the two patients kalemia is indirectly related to renal bicarbonate threshold. The findings might be interpreted to demonstrate an influence of potassium depletion on renal bicarbonate reabsorption in man. The observations are in agreement with the animal experiments of Kunau et al. [11], who equally dissociated the effect of extracellular fluid volume and potassium depletion on renal bicarbonate reabsorption.

Alkalosis in potassium-lepleted normal volunteers can be corrected despite continuing massive potassium deficits [10] by administration of sodium chloride

Table IV. Estimation of renal $\mathrm{HCO}_{3}{ }^{-}$threshold in patient $\mathrm{BE}(13$ months), ECF volume $=454 \mathrm{ml} / \mathrm{kg}$ body weight

\begin{tabular}{|c|c|c|c|c|c|c|c|c|c|c|c|}
\hline \multirow{3}{*}{ Date } & \multicolumn{3}{|c|}{ Blood } & \multicolumn{2}{|c|}{ Urine } & \multirow{3}{*}{$\begin{array}{c}\mathrm{C}_{\mathrm{In}}, \\
\mathrm{ml} / \mathrm{min} / \\
1.73 \mathrm{~m}^{2}\end{array}$} & \multirow{2}{*}{\multicolumn{3}{|c|}{$\frac{\text { Bicarbonate }}{\text { mmoles } / 100 \mathrm{ml} \mathrm{GFR}}$}} & \multirow{3}{*}{$\begin{array}{c}\text { Kalemia, } \\
\text { mEq/liter }\end{array}$} & \multirow{3}{*}{$\begin{array}{l}\text { Indicated rena } \\
\text { bicarbonate } \\
\text { threshold, } \\
\text { mmoles/liter } \\
\text { serum }\end{array}$} \\
\hline & \multirow{2}{*}{ pll } & \multirow{2}{*}{$\underset{\mathrm{mm} \mathrm{IIg}}{\mathrm{pCO}_{2}}$} & \multirow{2}{*}{$\underset{\substack{\mathrm{HCO}_{3}^{-} \\
\text {moles/liter } \\
\text { plasma }}}{\mathrm{Hel}^{2}}$} & \multirow{2}{*}{$\begin{array}{l}\mathrm{V} \\
\mathrm{ml} / \mathrm{min} / \\
1.73 \mathrm{~m}^{2}\end{array}$} & \multirow{2}{*}{ nil } & & & & & & \\
\hline & & & & & & & Filtered & Excreted & Reabsorbed & & \\
\hline \multirow[t]{2}{*}{$2 / 4 / 70$} & 7.45 & 31.0 & 21.4 & 4.62 & 7.45 & 158.9 & 2.14 & 0.077 & 2.063 & 3.30 & $<21.4$ \\
\hline & & & & 2.77 & 7.55 & 129.6 & & 0.065 & 2.075 & 3.10 & \\
\hline
\end{tabular}


alone. In the patient of Houston et al. [9], however, the alkalosis was not completely correctable by sodium supplements. Sodium repletion might have changed ECF volume to a different extent and therefore might have led to a different effect. On the other hand, correction of alkalosis is retarded by correction of potassium deficiency alone without correction of a sodium and chloride deficit [2]. If potassium deficiency is corrected together with a poorly reabsorbable anion, the anion is excreted at the cost of losing hydrogen ion rather than sodium, and therefore alkalosis may persist. Such mechanisms are not involved in the present studies since sodium and potassium were corrected simultaneously and together with chloride.

It was of interest to observe that the relative change of renal handling of bicarbonate was related to a distinct, but rather moderate increase of kalemia in both patients. Although serum potassium concentration had only moderately inproved, it is conceivable that intracellular potassium content had increased to a much greater extent. This possibility has been considered by Lennon and Lemann [12] as an increased intrinsic sodium reabsorptive capacity in potassium-depleted subjects. The same mechanisms might operate on hydrogen ion excretion. It has been shown by Grantham et al. [7] that in the absence of extracellular $\mathrm{pH}$ alterations plasma potassium concentration has a constant relation to intracellular potassium concentration, but that the relation is imprecisely defined when alterations of extracellular pH occur. Since marked alkalosis accompanied the hypokalemic states in the present study, and conversely both patients presented with a slight aciclosis after clietary potassium supplements, the remarkable change of renal bicarbonate threshold despite a moderate increase of extracellular potassium concentration might therefore be explained on the basis of the obscrvations of Grantham et al.

In contrast to our studies in hypokalemic states, hyperkalemia has been shown experimentally to cause renal tubular acidosis as a result of a bicarbonate wasting syndrome [6]. Hyperkalemia following human renal transplantation induces acidosis [8]. Edelmann [5] has observed a patient with hyperkalemia and renal tubular acidosis. Whereas we have demonstrated high bicarbonate threshold associated with hypokalemia, the observations of others indicate that conversely hyperkalemia is associated with low bicarbonate threshold.

\section{Summary}

Two patients with hypokalemia have been studied with respect to the correlation of serum potassium con- centration and renal bicarbonate threshold. Each patient was studied uncler two conditions: first with low levels of serum potassium, 1.7 and $1.6 \mathrm{mval} / \mathrm{liter}$, respectively, and second with higher levels of serum potassium, 2.4 and 3.2 mval/liter, respectively. Plasma volume and ECF volume were not significantly different in the two conclitions, and therefore an effect of plasma volume on renal bicarbonate threshold was excludecl. In both patients an indirect relation of serum potassium level and renal bicarbonate threshold was observed.

These studies have shown bicarbonate retention in hypokalemia. They supplement the observations found in the literature that hyperkalemin is associated with renal bicarbonate wasting. It seems possible now to assume an indirect relation between the state of potassium repletion and renal bicarbonate threshold.

\section{References and Notes}

1. Abbrecit, P. H.: Effects of potassium deficiency on renal function in the dog. J. Clin. Invest., 48: 432 (1969).

2. Bleich, H. L., Tanner, R. L., and Schwartz, W. B.: The induction of metabolic alkalosis by correction of potassium deficiency. J. Clin. Invest., 45: 573 (1966).

3. BrunNer, F. P., AND FrICK, P. G.: Hypokalemia, metabolic alkalosis and hypernatremia due to "massive" sodium penicillin therapy. Brit. Med. J., 4: 550 (1968).

4. Cannon, P. J., Heinemann, II. O., Albert, M. S., Laragit, J. H., ANI) W'INTFRs, R. W.: Contraction alkalosis after diuresis of edematous paticnts with ethacrynic acid. Ann. Intern. Med. $62,979,196.5$.

5. Eofimann, C. Mr.: Personal communication.

6. Gifibisci, G., Macleon, M. B., and Pitts, R. F.: Effect of adrenal steroids on renal tubular reabsorption of bicarbonate. Amer. J. Physiol., 183: 377 (1955).

7. Granthan, J. J., AND SCHLoerb, P. R.: Interrelation of potassium and hydrogen ion gradients in metabolic alkalosis. Amer. J. Physiol., 208: 1114 (1965).

8. Györy, A. Z., Steivart, J. H., George, C. R. P., Tiller, D. J., AND Edwards, K. D. G.: Renal tubular acidosis, acidosis due to hyperkalemia, hypercalcemia, disordered nitrate metabolism and other tubular dysfunctions following human renal transplantation. Quart. J. Med., 38: 231 (1969).

9. Houston, I. B., Boichis, II., ANd Edelmann, C. M., JR.: Fanconi syndrome with renal sodium wasting and metabolic alkalosis. Amer. J. Med., 44: 638 (1968).

10. Kassier, J. P., AND Scinwartz, W. B.: Correction of metabolic alkalosis in man without repair of potassium deficiency. Amer. J. Med., t0: 19 (1966).

11. Kunau, R. T., JR., Frick, A., Rector, F. C., JR., And Seldin, D. W.: Micropuncture study of the proximal tubular factors responsible for the maintenance of alkalosis during potassium deficiency in the rat. Clin. Sci., 34: 223 (1968).

12. I.fNNON, E. J., AND LemanN, J., Jk.: The eftect of a potassium deficient diet on the pattern of recovery from experimental mctabolic acidosis. Clin. Sci., 3t: 365 (1968).

13. Mork1s, R. C., JR.: Renal tubular acidosis. Mechanisms, 
classification and implications. New Engl. J. Med., 281: 1405 (1969).

14. OErLiker, O., AND Rossi, E.: The influence of extracellular fluid volume on the renal bicarbonate threshold. Pediat. Res., 3: 140 (1969).

15. Soriano, J. R., Boicins, H., and Ebelaiann, C. M., JR.: Bicarbonate reabsorption and hydrogen ion excretion in children with renal tubular acidosis. J. Pediat., 71: 802 (1967).

16. Veale, N., and Vetter, H.: Radioisotope Techniques in Clinical Research and Diagnosis, p. 224 (Butterworth, London, 1958).

17. Veall, N., and VetTek, H.: Radioisotope Techniques in
Clinical Rescarch and Diagnosis, p. 205 (Butterworth, London, 1958).

18. Parents of patients were informed about the planned studies in every detail, and consent was obtained prior to the studies.

19. Presented in part as an abstract at the Third Annual Meeting of the European Society for Pediatric Nephrology, Helsinki, 1969. Supported by Grants nos. 5311.3 and 3.56 .68 from the Swiss National Foundation for Scientific Research.

20. Requests for reprints should be addressed to: O. OEtLiker, M.D., Renal Unit, Department of Pediatrics, University of Berne, Berne, Switzerland.

21. Accepted for publication January 7, 1971. 